\title{
Pengembangan Block Board Varian Baru Berbasis Core dari Komposit Partikel Kayu Kelapa Sawit
}

\author{
Indra Mawardi ${ }^{1}$, Yuniati ${ }^{2}$, dan Saifuddin ${ }^{3}$ \\ 1,2,3Jurusan Teknik Mesin Politeknik Negeri Lhokseumawe \\ Jl. Banda Aceh-Medan km 280 Buketrata, Lhokseumawe \\ Telp.0645 42670, Fax 064542785 \\ Email: ddx_72@yahoo.com
}

\begin{abstract}
ABSTRAK
Penelitian ini bertujuan mengkaji kelayakan kayu kelapa sawit (KKS) sebagai material core pada pembuatan block board. Material core dibentuk menjadi komposit partikel dengan PS sebagai matriks. Komposit dibuat dengan variasi fraksi berat 30:70, 40:60 dan 50:50. Block board dibentuk dengan melapisi core dengan viner jenis kayu merantidan menggunakan urea formadehida sebagai perekat. Block board dikempa sebesar $20 \mathrm{~kg} / \mathrm{cm}^{2}$ selama 15 menit pada suhu ruang. Pengujian sifat mekanis yang dilakukan meliputi; modulus patah (MOR), geser tarik, dan kuat tarik sekrup. Sedangkan pengujian sifat fisis yang dilakukan adalah pengujian kadar air, kerapatan dan pengembangan tebal. Pengujian block board mengacu standar SNI 015008.2-2000. Hasil penelitian diperoleh karakteristik mekanis block board; MOR berkisar 145,6$204,2 \mathrm{~kg} / \mathrm{cm}^{2}$, kekuatan geser 4,63-7,23kg/ $\mathrm{cm}^{2}$, dan kuat tarik sekrup 112,43-149,97 kgf. Keteguhan rekat maksimum block board terjadi pada komposisi core 30:70 sebesar 14,45 $\mathrm{kg} / \mathrm{cm}^{2}$. Sifat fisis block board; kerapatan berkisar 0,63-0,85 g/cm³, kadar air 1,44-2.01\%, dan pengembangan tebal 2,57-3,49\%. Sifat mekanis dan fisis block board banyak dipengaruhi oleh sifat mekanis dan fisis material core. Secara umum block board dengan core dari komposit partikel KKS-PS telah memenuhi Standar Nasional Indonesia (SNI 01-5008.2-2000).
\end{abstract}

Kata kunci: Block board, core, partikel komposit, viner meranti.

\begin{abstract}
This experiment looked into the technical feasibility of using oil-palm wood (OPW) particles as the core material in block board manufacture. The OPW particles were shaped into the composite for such core using the polystyrene (PS) as matrix. In the composite particles, the proportion of $O P W$ and $P S$ was arranged in 3 variation $(w / w)$, i.e. 30:70, 40:60, and 50:50. Afterwards, the resulting OPW-PS composite was sandwich between veneers of meranti hardwood using urea formaldehyde adhesive. The sandwich assembly was then pressed into the so-called block board. After conditioning, the block board sustained the test on physical and mechanical properties. The mechanical test comprised modulus of rupture (MOR), shear strength under tension load (SSTL), and screw-holding power (SHP), while the physical test covered moisture content, density, and thickness swelling. Those overall test referred to the specification of Indonesian National Standard SNI 01-5008.2-2000. Mechanical properties of block board varied, i.e. MOR about 145,6-204,2 $\mathrm{kg} / \mathrm{cm}^{2}$, SSTL 4,6-7,23kg/ $\mathrm{cm}^{2}, B S 9,26-14,46 \mathrm{~kg} / \mathrm{cm}^{2}$, and $S H P$ 112,4-149,97 kgf.Physical properties also varied, i.e. density $0,63-0,85 \mathrm{~g} / \mathrm{cm}^{3}$, moisture content 1,44-2.01\%, and thickness swelling 2.57-3,49\%. Greater proportion of PS brought about the increase in density, but slight decreases in moisture content and thickness swelling. The overall physical and mechanical properties of the block boar could satisfy the SNI specification (SNI 015008.2-2000).
\end{abstract}

Keywords: Block board, composite particles, core, merantiveneer.

\section{PENDAHULUAN}

Permintaan terhadap barang-barang yang terbuat dari kayu semakin meningkat dan bervariasi, seperti: perkakas rumah tangga, furniture, dinding penyekat, dan lainnya. Disisi lain kayu mulai sulit didapat,baik jumlah maupun kualitasnya sehingga industri furniture beralih ke penggunaan produk subtitusi kayu seperti plywood, block board, papan partikel, teak board, dan laminboard sebagai material alternatif pengganti kayu utuh.

Block board merupakan salah satu produk industri perkayuan yang memiliki prospek cukup baik saat sekarang dan masa mendatang. Block 
board memiliki lapisan utama berupa core dari potongan kayu dan dilaminating dengan viner. Umumnya material core block board berasal dari sisa pengolahan kayu di industri olahan kayu, sehingga tidak memerlukan persyaratan kualitas bahan baku yang tinggi.

Seiring dengan peningkatan industri perkayuan di Indonesia, ketersediaan kayu di hutan semakin menurun dari tahun ketahun. Data Direktorat Bina Pengembangan Hutan Tanaman [1], realisasi produksi kayu bulat periode 1992 berkisar antara 19 sampai 28 juta $\mathrm{m}^{3}$ per tahun dan pada tahun antara 2001 sampai 2005 berkisar antara 9 sampai 13 juta $\mathrm{m}^{3}$ per tahun. Hal ini berpengaruh juga terhadap kebutuhan bahan baku kayu bagi industri block board.

Untuk mengatasi kekurangan akan kebutuhan ini harus dicari jenis bahan alternatif yang dapat menggantikan kedudukan kayu tanpa menimbulkan kerusakan lingkungan. Kayu kelapa sawit (KKS) merupakan salah satu alternatif sumber bahan baku kayu yang renewable dan tingkat ketersediaannya yang berlimpah sepanjang tahun. Menurut Lisman [2], kayu kelapa sawit mempunyai potensi penghasil kayu yang cukup besar. Dengan luas perkebunan kelapa sawit pada tahun 2005 tercatat sekitar 5,59 juta ha. Hasil penelitian mencatat volume batang kelapa sawit rata-rata 1,72 $\mathrm{m}^{3} /$ pohon, apabila diambil $75 \%$ dari populasi pohon akan diperoleh 128 pohon/ha, maka akan tersedia volume batang kayu sebesar 165,12 m³/ha.

Pemanfaatan secara terencana kayu kelapa sawit tua untuk bahan baku industri kayu akan memberikan peran strategis dalam mempertangguh usaha kelapa sawit dan sumber alternatif bahan baku perkayuan yang ramah lingkungan, serta menyelesaikan masalah limbah, sekaligus dapat merupakan katup pengaman kerusakan hutan tropis. Disamping itu mudah didapat, proses perlakuan yang menjadikan batang kelapa sawit itu menjadi bahan baku kayu tidak membutuhkan biaya yang terlalu tinggi. Melalui rekayasa terhadap karakteristik dasar KKS yang memiliki kualitas yang rendah dibanding dengan kayu, diharapkan KKS menjadi bahan baku funiture yang potensial.

KKS dapat dijadikan sebagai bahan baku pengganti atau substitusi untuk industri kayu seperti industri pulp dan perabot karena tingkat ketersediannya yang berlimpah sepanjang tahun. Batang monokotil seperti KKS, mempunyai jaringan parenkim diantara bundel-bundel seratnya, yang semula dalam kayu segar masih mengandung air. Setelah pengeringan jaringan ini banyak yang rusak sehingga membentuk pori-pori yang cenderung menyerap cairan polar (diantaranya air). Oleh karena itu perlu dilakukan modifikasi melalui pengisian pori kayu dengan polimer agar mampu meningkatkan stabilitas kayu dengan semakin banyaknya rongga-rongga sel kayu yang terisi oleh bahan polimer [3]. Karakteristik KKS utuh memiliki rapat massa $0,38 \mathrm{~g} / \mathrm{cm}$, modulus elastisitas $12.469,46 \mathrm{~kg} / \mathrm{cm}^{2}$, dan modulus patah $117,00 \mathrm{~kg} / \mathrm{cm}^{2}$, [2]. Dalam tulisan ini disajikan hasil penelitian pemanfaatan komposit partikel KKS sebagai core pada pembuatan block board KKS.

\section{METODE PENELITIAN}

\section{Bahan}

Bahan-bahan yang digunakan dalam penelitian ini antara lain partikel kayu kelapa sawit, poly tyrene (PS) sebagai matriks, $\mathrm{NaOH}$ (alkali), benzoil peroksida, maleated coupling agent, dan silena (pelarut organik).

\section{Rancangan Penelitian}

\section{Persiapan Partikel KKS}

Partikel KKS yang digunakan berasal dari kayu kelapa sawit tua.Partikel diserut dan disortir berdiameter $<5 \mathrm{~mm}$. Partikel KKS direndam di dalam 5\% NaOH selama 4 jam [4]. Partikel KKS dinetralkan dari efek $\mathrm{NaOH}$ dengan pencucian menggunakan air.Selanjutnya partikel KKS dikeringkan beberapa waktu hingga mencapai kering udara.

\section{Pembuatan Core (komposit partikel KKS)}

Proses pembuatan core diawali dengan membuat matriks. Matriks dibuat dengan mencampur hingga rata bahan-bahan seperti $P S$, silena, coupling agent dan benzoil peroksida. Penggunaan coupling agent sebanyak 8\% dari berat PS, benzoil peroksida sebanyak $8 \%$ dari coupling agent, dansilena $200 \%$ dari berat $P S$.

Core yang berupa komposit partikel KKS dibuat dengan mencampur matriks dan partikel KKS menggunakan mesin ekstrusi pada putaran $50 \mathrm{rpm}$ pada temperatur $50-60^{\circ} \mathrm{C}$. Komposit partikel KKS yang telah tercampur homogen dimasukan ke dalam cetakan dengan ketebalan $15 \mathrm{~mm}$. Proses pencetakan komposit partikel pada suhu ruang dan dibiarkan kering selama 14 hari sebelum dipakai sebagai core pada pembuatan block board. Variasi unsur pembentuk core berdasarkan fraksi berat KKS-PS, yaitu perbandingan 30:70, 40:60 dan 50:50.

\section{Pembuatan Block Board}

Pembuatan block board dilakukan dengan melapisi kedua permukaan core dengan viner (susunan 3 lapisan, yaitu viner + core + viner). Material viner adalah plywood dari jenis kayu meranti dengan ketebalan 2,5 mm. Perekatan viner dengan core menggunakan perekat urea formaldehida dan dikempa sebesar $20 \mathrm{~kg} / \mathrm{cm}^{2}$ selama 15 menit pada suhu ruang. 


\section{Pengujian}

Pengujian sifat mekanis meliputi modulus patah (MOR), keteguhan rekat dan kuat tarik sekrup. Sedangkan untuk sifat fisis meliputi kerapatan, kadar air dan pengembangan tebal. Pola pemotongan spesimen uji mengacu pada standar SNI 01-5008.2-2000 [5]. Pengujian keteguhan rekat block board dilakukan dengan uji geser tarik. Spesimen uji geser tarik dibuat dengan ukuran 100 $\mathrm{mm} \times 25 \mathrm{~mm}$, dengan ukuran bidang geser adalah $25 \mathrm{~mm} \times 25 \mathrm{~mm}$. Takik bidang geser dibuat sedalam lapisan core dengan lebar tidak lebih dari $3 \mathrm{~mm}$. Setengah dari spesimen mempunyai orientasi retak kupas terbuka dan sisi lainnya mempunyai orientasi retak tutup. Spesimen dibuat sebanyak 7 buah untuk masing-masing komposisi core.

\section{HASIL DAN PEMBAHASAN}

\section{Sifat Mekanis}

\section{Modulus Patah (MOR)}

Pengujian MOR dilakukan untuk melihat kemampuan block board terhadap gaya maksimal yang menyebabkan block board patah (Gambar 1).

Nilai MOR block board dengan core komposit partikel KKS-PS berkisar antara 145,6 kg/ $/ \mathrm{cm}^{2}$ sampai $204,2 \mathrm{~kg} / \mathrm{cm}^{2}$. Nilai MOR maksimum didapat pada block board KKS yang menggunakan core komposit partikel dengan komposisi $40 \%$ KKS dan 60\% PS. Tingginya nilai MOR block board pada variasi 40:60 lebih dipengaruhi oleh tingginya nilai MOR core pada komposisi tersebut. Pada Gambar 1 juga terlihat MOR core optimum pada perbandingan KKS-PS sebesar 40:60. Peningkatan porsi KKS menjadi 50:50 dan peningkatan porsi PS menjadi 30:70 cenderung menurunkan MOR material core. Fenomena ini diakibatkan shear (geser) partikel KKS dan PS sewaktu mengalami uji MOR (bending).

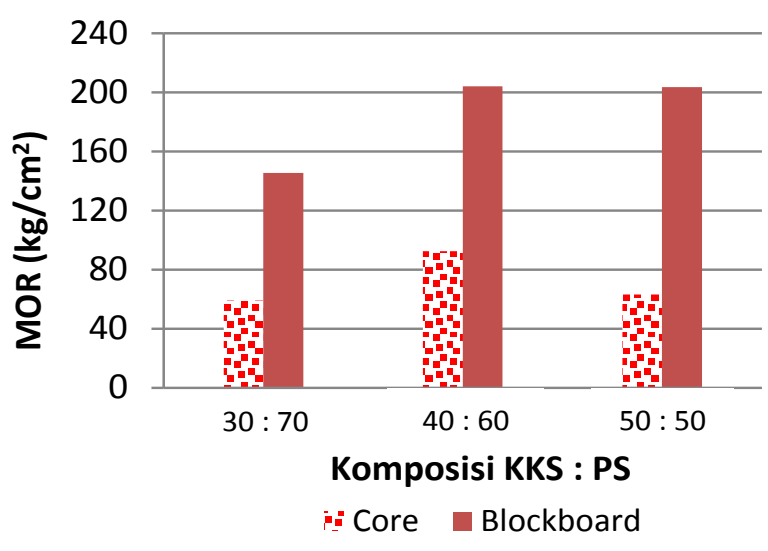

Gambar 1. Nilai MOR Block Board
Secara keseluruhan MOR block board lebih tinggi dibandingkan MOR material core (Gambar 1), terindikasi kuat dengan peran 2 lapisan viner yang direkatkan pada permukaan bawah dan atas bagian core tersebut (komposit KKS-PS) yang meningkatkan ketahanan kompres dan ketahanan tarik pada saat dilakukan MOR (in bending). Hal yang menarik adalah walaupun porsi KKS-PS sebesar 40:60 memiliki nilai MOR maksimal untuk block board dan material core, akan tetapi peningkatan porsi KKS menjadi 50:50, tidak merubah secara nyata MOR block board. Ini memperkuat indikasi sebelumnya yaitu pada porsi KKS-PS $=$ 40:60 fenomena geser bagian core yang positif ikut berperan positif pula terhadap MOR block board. Pada porsi KKS-PS 50:50 walaupun terindikasi negatif terhadap fenomena geser, akan tetapi MOR block board menyamai porsi 40:60. Hal ini lebih disebabkan peran lapisan viner bagian atas dan bawah pada block board.

Nilai MOR maksimum block board dengan core komposit partikel KKS-PS pada perbandingan 40:60 sebesar $204,2 \mathrm{~kg} / \mathrm{cm}^{2}$ lebih rendah dibandingkan block board yang dibuat 5 lapis menggunakan core dari strip kayu kelapa sawit, yaitu $393,9 \mathrm{~kg} / \mathrm{cm}^{2}$ [6]. Nilai maksimum MOR block board yang dihasil $\left(204,2 \mathrm{~kg} / \mathrm{cm}^{2}\right)$ hampir menyamai nilai MOR ratarata block board sengon dengan venir silang kayu tusam 5 lapis yaitu $253,27 \mathrm{~kg} / \mathrm{cm}^{2}$ yang diuji pada arah sejajar serat dan $201,14 \mathrm{~kg} / \mathrm{cm}^{2}$ yang diuji pada arah tegak lurus serat [7]. Nilai MOR core (komposit KKS-PS) secara keseluruhan (Gambar1) lebih rendah dari pada MOR KKS utuh, yaitu 117,00 $\mathrm{kg} / \mathrm{cm}^{2}$ [2], akan tetapi dalam bentuk block board dimana bagian core nya dengan porsi 40:60 dan 50:50 untuk KKS:PS (berturut-turut) $>200 \mathrm{~kg} / \mathrm{cm}^{2}$ lebih besar dari pada MOR KKS utuh tersebut.

Secara keseluruhan block board dengan core komposit partikel KKS-PS pada porsi 40:60 dan 50:50 telah memenuhi Standar Jerman untuk block board sejajar dan tegak lurus serat mempersyaratkan MOR minimum $200 \mathrm{~kg} / \mathrm{cm}^{2}$.

\section{Keteguhan Rekat}

Pengujian keteguhan rekat dilakukan untuk mengetahui tingkat kekuatan rekat antara viner dan core.Nilai keteguhan rekat didapat dari hasil perkalian nilai geser tarik dengan koefesien dari hasil perbandingan tebal vinir dan core. Kekuatan geser tarik block board (core dari komposit partikel KKS-PS) berkisar antara 4,63 kg/ $\mathrm{cm}^{2}$ sampai 7,23 $\mathrm{kg} / \mathrm{cm}^{2}$, dengan kekuatan geser tarik tertinggi terjadi pada komposisi 30:70 (Gambar 2).

Dari Gambar 2 terlihat kekuatan geser tarik block board cenderung meningkatnya dengan semakin besar persentase PS terhadap partikel KKS pada core. Hal ini menunjukan peran penting 
PS sebagai pengikat dalam meningkatkan kuat geser tarik.Fenomena ini terjadi dikarenakan PS yang telah melunak (melting) memasuki pori-pori partikel KKS dan meningkatkan intensitas ikatan antar muka antara KKS dan PS. Ini mengakibatkan PS pada saat mengeras (suhu kamar) berpengaruh positif pada karakteristik adesi KKS-PS dan karakteristik kohesi pada PS sendiri.

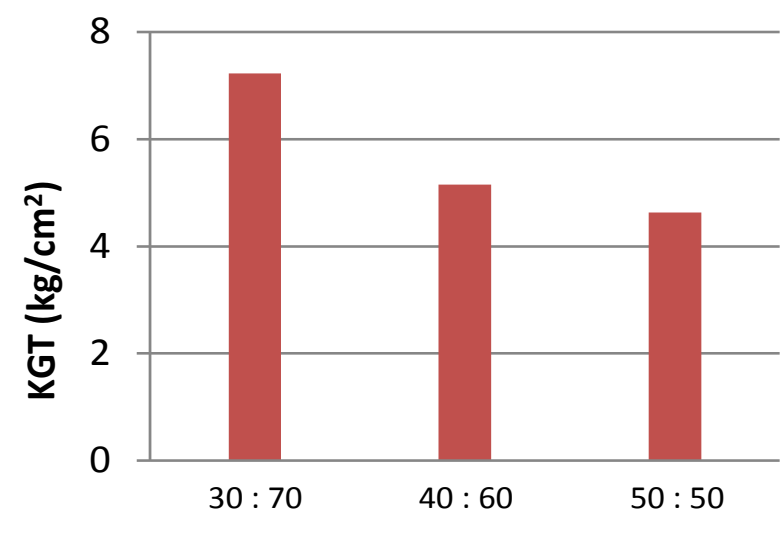

Komposisi KKS : PS

Gambar 2. Kekuatan Geser Tarik (KGT) Block Board

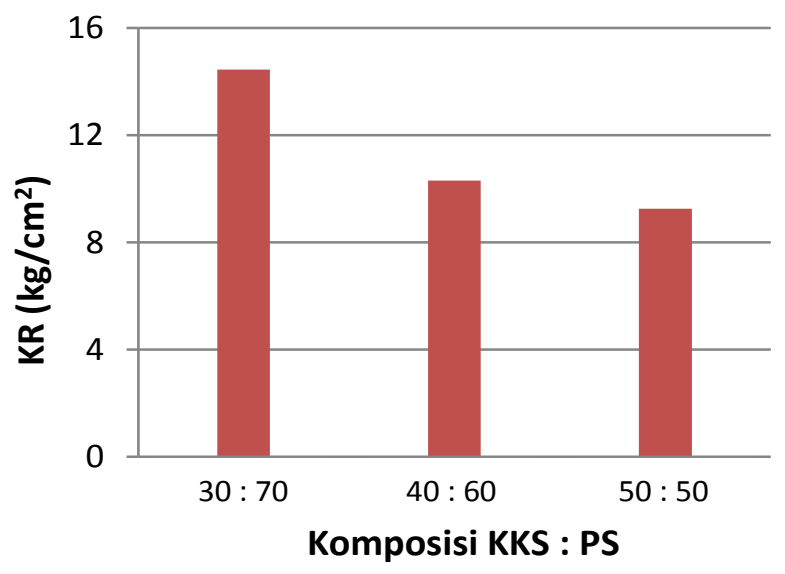

Gambar 3. Keteguhan Rekat (KR) Block Board

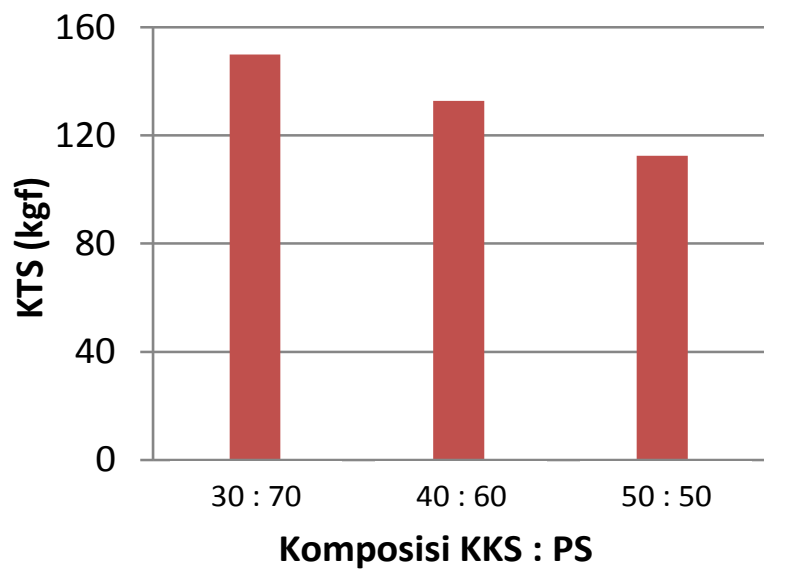

Gammbar 4. Kuat Tarik Sekrup (KTS) Block Board
Nilai keteguhan rekat mengikuti nilai kekuatan tarik geser,semakin besar nilai kekuatan geser tarik maka semakin besar nilai keteguhan rekat (Gambar 3). Hal ini dikarenakan nilai keteguhan rekat merupakan hasil perkalian kekuatan geser tarik dengan koefisien pembanding tebal lapisan core terhadap tebal lapisan muka. Keteguhan rekat block board dengan core komposit partikel KKS berkisar antara $9,26 \mathrm{~kg} / \mathrm{cm}^{2}$ sampai $14,45 \mathrm{~kg} / \mathrm{cm}^{2}$. Keteguhan rekat block board dengan core komposit partikel KKS memenuhi standar SNI 01-5008.22000, yang mempersyaratkan nilai minimum keteguhan rekat sebesar $7 \mathrm{~kg} / \mathrm{cm}^{2}$.

Jika dikompilasi dengan penelitian Iskandar [7], keteguhan rekat block board sengon dengan venir silang kayu tusam 5 lapis yang berkisar antara $7,45 \mathrm{~kg} / \mathrm{cm}^{2}$ hingga $9,8 \mathrm{~kg} / \mathrm{cm}^{2}$, nilai keteguhan rekat block board dengan core komposit partikel masih lebih baik.

\section{Kuat Tarik Sekrup}

Kuat tarik sekrup menunjukan kemampuan block board menahan sekrup yang ditancap agar sekrup tidak lepas.Nilai kuat tarik sekrup block board menunjukan kecendrungan meningkat seiring berkurangnya kadar KKS dalam core (Gambar 4).

Nilai kuat tarik sekrup block board dengan core komposit partikel KKS-PS berkisar antara 112,43 kgf sampai 149,97 kgf. Kuat tarik sekrup block board lebih dipengaruhi oleh kerapatan dan jumlah PS dalam material core yang meningkat. Hal ini memperkuat indikasi dengan peningkatan porsi PS berdampak positif terhadap kerapatan internal struktur core. Komposisi PS yang lebih besar dibandingkan partikel KKS pada material core dapat menyebabkan ulir sekrup lebih banyak menyentuh PS sehingga sekrup tidak mudah tercabut.

Nilai kuat tarik sekrup block board KKS jauh melebihi nilai maksimum kuat tarik sekrup block board yang dihasilkan Desyanti [6], yang menggunakan material core dari strip KKS, yaitu 45,75 kgf. Hal ini menunjukan, perlakuan KKS menjadi komposit partikel dapat meningkatkan kekuatan tarik sekrup.

\section{Sifat Fisis}

\section{Kerapatan}

Kerapatan block board dengan core komposit partikel KKS berkisar antara $0,63 \mathrm{~g} / \mathrm{cm}^{3}$ sampai $0,85 \mathrm{~g} / \mathrm{cm}^{3}$. Rata-rata hasil pengujian kerapatan block board KKS untuk berbagai variasi komposisi material core disajikan pada Gambar 5.

Kerapatan terendah didapat pada komposisi material core 50:50 dan kerapatan maksimum pada komposisi material core 30:70. 


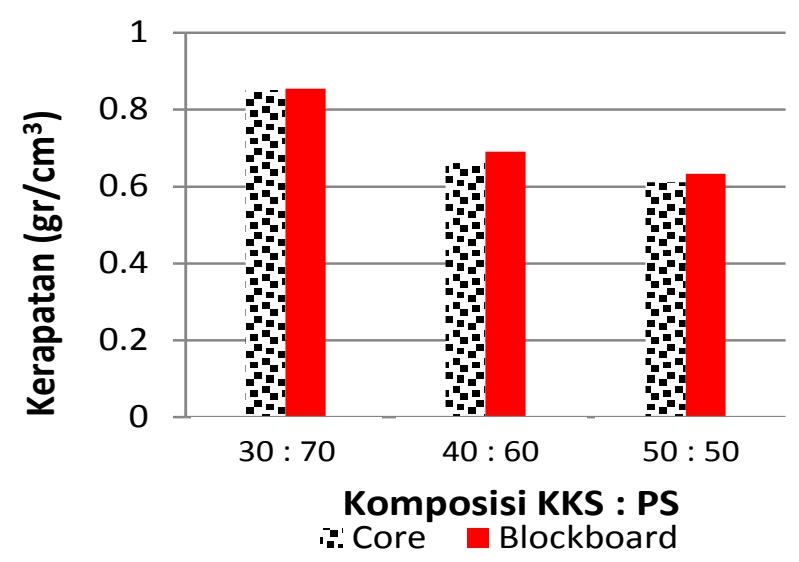

Gambar 5. Kerapatan Block Board

Fenomena ini menunjukan bahwa kerapatan block board dipengaruhi oleh nilai kerapatan dari komposit partikel sebagai material core. Selain itu kerapatan juga dipengaruhi oleh berat jenis material pembentuk core. Berat jenis PS yang lebih besar dibandingkan KKS, ditambah porsi PS yang lebih besar pada material core, maka kerapatan block board akan meningkatkan. Pada Gambar 5 juga terlihat, penambahan viner pada bagian atas dan bawah tidak banyak berpengaruh terhadap kerapatan block board, dan perubahan kerapatan block board konsisten dengan perubahan kerapatan pada bagian core.

Fenomena peningkatan kerapatan seiring bertambahnya porsi PS terhadap KKS, ternyata konsisten dengan yang terjadi pada keteguhan rekat (Gambar 3) dan kuat tarik sekrup (Gambar 4).Hal ini memperkuat indikasi, semakin membaik ikatan antara marik antara PS dan partikel KKS pada material core seiring dengan peningkatan jumlah PS.

Kerapatan block board dengan material core komposit partikel $\left(0,63-0,85 \mathrm{~g} / \mathrm{cm}^{3}\right)$ masih lebih baik dibandingkan kerapatan block board yang menggunakan strip KKS yaitu $0,48 \mathrm{~g} / \mathrm{cm}^{3}-0,58 \mathrm{~g} / \mathrm{cm}^{3}[6]$, dan kerapatan block board sengon dengan menggunakan vinir kayu tusam yaitu antara $0,41 \mathrm{~g} / \mathrm{cm}^{3}$ sampai $0,44 \mathrm{~g} / \mathrm{cm}^{3}$, [7]. Nilai kerapatan secara tidak langsung akan mempengaruhi nilai sifat mekanis kuat tarik sekrup.

\section{Kadar Air}

Gambar 6 memperlihatkan kadar air block board, nilai kadar air block board yang dihasilkan berkisar antara $1,44 \%$ sampai $2.01 \%$. Nilai kadar air yang didapat memenuhi SNI 01-5008.2-2000 mempersyaratkan nilai kadar air tidak boleh $>14 \%$.

Pada Gambar 6 terlihat kadar air cenderung sedikit menurun dengan peningkatan porsi PS, baik pada block board maupun pada bagian core. Kadar air block board tertinggi $(2,01 \%)$ terjadi pada komposisi core KKS-PS 50:50 dan terendah (1,44\%) pada komposisi 30:70.

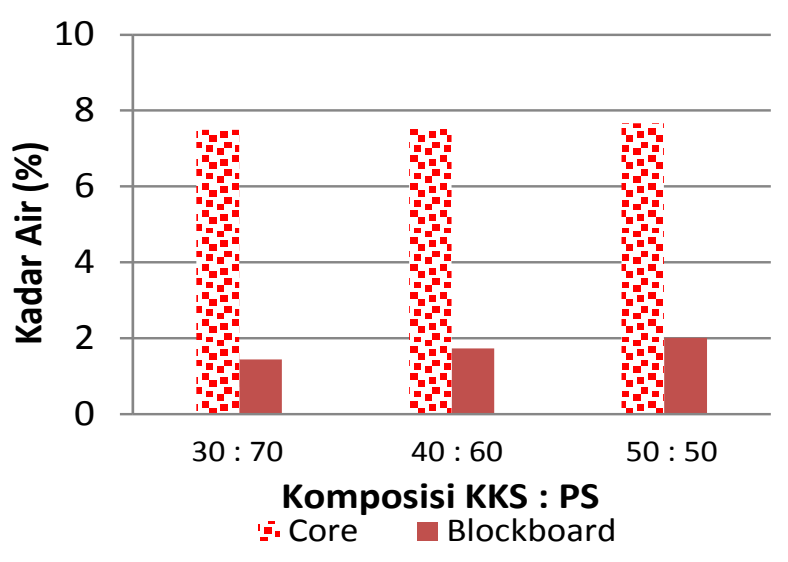

Gambar 6. Kadar Air Block Board

Kadar air block board dengan core dari komposit partikel KKS jauh lebih baik jika dibandingkan dengan block board yang menggunakan core dari strip KKS 6] yaitu, 9,5\%-14,4\%. Hal ini menunjukan bahwa penggunaan material core dalam bentuk komposit sangat berpengaruh terhadap sifat higroskopis block board. PS yang berfungsi sebagai unsur pengikat (matriks) pada komposit (core) dapat menutupi secara baik partikel-partikel KKS yang mengandung hemiselulosa dan selulosa serta senyawa-senyawa lainyang bersifat higroskopis (mudah menyerap air). Persentase PS yang lebih banyak akan lebih mudah menutupi partikel KKS dengan sempurna sehingga air sulit terserap oleh partikel KKS.

Meskipun secara konsisten kadar air block board mengikuti kadar air dari material core, akan tetapi kadar air core dari komposit partikel KKS jauh lebih besar dibandingkan dengan kadar air block board. Ini dikarenakan core sebelum ditutupi viner mempunyai daerah kontak dengan air yang lebih luas, sehingga air lebih mudah terserap. Disamping material viner yang mempunyai kerapatan yang lebih baik dibandingkan core. Dengan penggunaan viner pada permukaan muka dan belakang dari core sifat higroskopis block board dapat direduksi hingga 400\%. Kadar air yang terlalu tinggi akan berpengaruh pada pengembangan tebal nantinya.

\section{Pengembangan Tebal}

Sifat fisis pengembangan tebal merupakan faktor penting pada saat block board diaplikasikan di daerah yang lembab atau basah. Nilai pengembangan tebal komposit block board dengan core komposit partikel KKS berkisar antara 2,57 sampai $3,49 \%$. Pengembangan tebal maksimum terjadi pada block board dengan komposisi material core 50:50, dan yang terendah pada komposisi 30:70 (Gambar 7). 


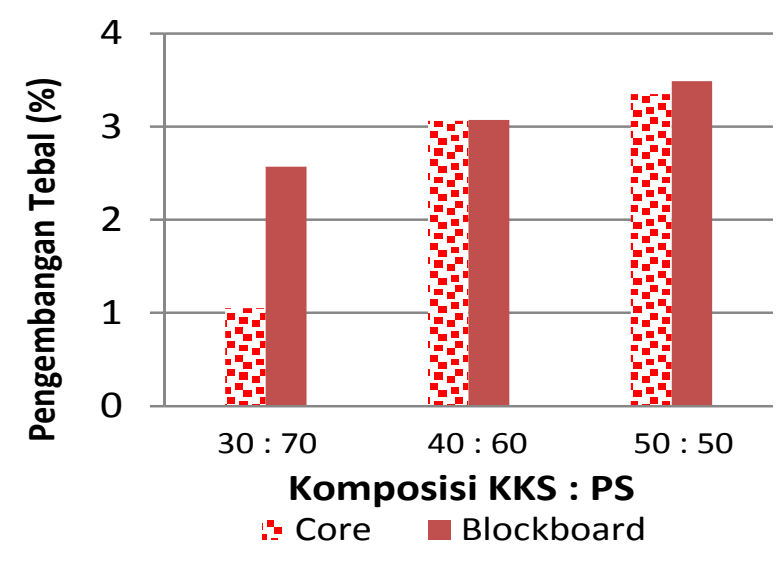

Gambar 7. Pengembangan Tebal Block Board

Terdapat kecenderungan yaitu semakin besar porsi PS terhadap porsi KKS, maka pengembangan tebal bagian core semakin menurun. Ini dikarenakan dengan porsi PS yang lebih besar, maka akan semakin banyak PS (bersifat non polar) yang memasuki pori-pori KKS (bersifat polar) dan berikatan (melapisi) KKS tersebut. Akibatnya polaritas komposit KKS-PS menurun, yang diikuti dengan penurunan pengembangan tebalnya. Dengan perkataan lain semakin rendah porsi PS (porsi KKS meningkat) maka polaritas core meningkat.

Lebih lanjut perubahan pengembangan tebal pada bagian core ternyata hampir konsisten dengan perubahan pada block board (Gambar 7), dan secara keseluruhan pengembangan tebal block board lebih besar dari pada pengembangan bagian core. Hal ini dapat dijelaskan karena lapisan terluar block board berupa viner (bersifat polar), sedangkan dalam bentuk komposit (core) keseluruhan lapisan luarnya juga komposit KKS-PS (bersifat kurang polar).

Perbedaan (lebih rendahnya) antara pengembangan tebal bagian core dengan pengembangan tebal block board pada porsi KKS-PS 30:70 diakibatkan terjadinya penurunan polaritas pada pori tersebut. Penurunan polaritas tersebut diakibatkan kurang efektifnya ikatan antar muka (interface) antara bagian core (kurang polar) perekat dari $U F$ (bersifat polar) viner (kurang polar), sehingga air lebih mudah penetrasi ke dalam pori-pori KKS. Disamping itu, semakin banyak partikel KKS yang tidak terikat oleh perekat juga akan memudahkan air melakukan penetrasi dan core akan mudah mengembang.

Jika dikompilasi dengan Desyanti [6] yang menggunakan KKS berbentuk strip sebagai material core pada pembuatan block board dengan ketebalan 0,5-1,6 cm, menghasilkan pengebangan tebal antara 2,2 sampai 5,9\%, block board menggunakan core dari komposit partikel KKS masih lebih baik (2,57-3,49\%).

\section{KESIMPULAN}

Sifat mekanis block board dengan core beruapa komposit partikel KKS-PS dan lapisan terluar adalah viner kayu meranti menunjukan variasi yaitu MOR 145,6-204,2 kg/cm² (MOR maksimum pada porsi KKS-PS 40:60); keteguhan rekat (KT) 9,26-14,46 kg/cm²; dan kuat tarik sekrup (KTS) antara 112,43 sampai 149,97 kgf. Peningkatan porsi PS terhadap porsi KKS cenderung meningkatkan $\mathrm{KR}$, dan KTS, dan nilai KR dan KTS block board yang maksimum adalah porsi KKs-PS 30:70. Sifat fisis block board juga bervariasi, yaitu kerapatan berkisar antara 0,63 sampai $0,85 \mathrm{~g} / \mathrm{cm}^{3}$, kadar air 1,44-2.01\%, dan pengembangan tebal antara 2,57 sampai $3,49 \%$. Peningkatan porsiKKS terhadap PS cenderung menurunkan kerapatan dan meningkatkan pengembangan tebal. Perubahan porsi PS terhadap porsi KKS, walau tidak berpengaruh nyata tetepi cenderung menurunkan kadar air. Sifat mekanis dan fisis block board dengan core komposit partikel KKS memenuhi persyaratan sifat menurut Standar Nasional Indonesia (SNI 01-5008.2-2000).

\section{UCAPAN TERIMAKASIH}

Penulis menyampaikan terimakasih atas bantuan dana penelitian yang diberikan Dikti melalui DIPA Politeknik Negeri Lhokseumawe Tahun Anggaran 2012, sesuai dengan Surat Perjanjian Penugasan dalam Rangka Pelaksanaan Penelitian Hibah Bersaing Nomor: 035/PL20/R8/ SPP-PLHB/2012, tanggal 08 Februari 2012

\section{DAFTAR PUSTAKA}

[1] Direktorat Bina Pengembangan Hutan Tanaman. 2006. Ketersediaan Pasokan Kayu Dari Hutan Tanaman untuk Memenuhi Bahan Baku Industri Perkayuan. Workshop "Pasokan Bahan Baku Kayu untuk Industri Perkayuan di Indonesia”, tanggal 12-13 Oktober 2006. di Twin Plaza Hotel Jakarta.

[2] Lisman, S. dan S.D. Waluyo. 2007. Analisa Konsumsi Kayu Nasional. (http://www.rimbawan. com/pdf, 12 April 2010)

[3] Zukarnain. Impregnasi Resin Pinus Merkusidan Asam Akrilat ke dalam Kayu Kelapa Sawit Menggunakan Berbagai Pelarut. Tesis Kimia. SPs USU Medan. 2000.

[4] Indra, M. Mutu Papan Partikel dari Kayu Kelapa Sawit (KKS) Berbasis Perekat Polystyrene. Jurnal Teknik Mesin, 11(2): 91-96. Petra Surabaya. 2009. 
[5] _ _ 2002. Kayu lapis penggunaan umum. Badan Standarisasi Nasional. Jakarta.SNI 015008.2-2000.

[6] Desyanti. Pemanfaatan Kayu Sawit sebagai Core Blockboard. Tesis Magistes Sain, IPB, Bogor. 2000.
[7] Iskandar M.I. dan Sulastiningsih. Sifat Blockboard Sengon dengan Venir Silang Kayu Tusam. Jurnal Penelitian Hasil Hutan, 24(2). Pusat Penelitian dan Pengembangan Hasil Hutan dan Sosial Ekonomi Kehutanan. Bogor. 2006. 